Policy Research Working Paper 2289

Exchange Rate

Overvaluation and

Trade Protection

Lessons from Experience

Howard J. Shatz

David G. Tarr
Lessons from world

experience about the

consequences of exchange

rate overvaluation (the

frequent cause of

trade crises), the

consequences of trying to

defend an overvalued

exchange rate, and the most

appropnate policies for

resolving an overvaluation

The World Bank

Development Research Group

Trade

February 2000 


\section{Summary findings}

Despite a trend toward more flexible exchange rates, more than half the world's countries maintain fixed or managed exchange rates. In the 1980 s and 1990s, developing countries as a group progressively liberalized their trade regimes, but some governments defend their exchange rate in actions that run counter to long-run plans for liberalization.

Without discussing the relative merits of fixed and flexible exchange rate systems, Shatz and Tarr note that exchange rate management in many countries has resulted in overvaluation of the real exchange rate. Roughly 25 percent of the countries for which data are available have overvalued exchange rates, with black market premiums from 10 percent to more than 100 percent.

After surveying the literature, the authors present lessons from experience about what has worked (or not) in response to crises involving external shocks and external trade deficits - and why.

Trying to defend an overvalued exchange rate with protectionist trade policies is a classic pattern, but experience shows such protection to significantly retard the country's growth and delay its integration into the world trading community. In fact, an overvalued exchange rate is often the root cause of protection, preventing the country from returning to more liberal trade policies that allow growth and integration into the world community without exchange rate adjustment.

Most developing countries have downward price and wage rigidities and, with an external trade deficit, require some form of nomirial exchange rate adjustment to restore external equilibrium.

Shatz and Tarr present cross-country econometric and case study evidence - citing examples from Argentina, Chile, Ghana, the Republic of Korea, Malaysia, Turkey, Uruguay, and Sub-Saharan Africa (including the CFA zone) - that overvalued exchange rates reduce economic growth.

Defending the exchange rate, they show, has no medium-term benefits, since falling reserves will eventually force devaluation. Better to have devaluation occur without further debilitating losses in reserves and lost productivity because of import controls. After devaluation the exchange rate will reach a new equilibrium, strongly influenced by government and central bank policies.

This paper - a product of Trade, Development Research Group - is part of a larger effort in the group to assess the consequences of trade liberalization in developing countries. Copies of the paper are available free from the World Bank, 1818 H Street, NW, Washington, DC 20433. Please contact Lili Tabada, room MC3-333, telephone 202-473-6896, fax 202-522-1159, email address 1tabada@worldbank.org. Policy Research Working Papers are also posted on the Web at www.worldbank.org/research/workingpapers. David Tarr may be contacted at ctarr@worldbank.org. February 2000. (27 pages)

The Policy Research Working Paper Series disseminates the findings of work in progress to encourage the exchange of ideas about development issues. An objective of the series is to get the findings out quickly, even if the presentations are less than fully polished. The papers carry the names of the authors and should be cited accordingly. The findings, interpretations, and conclusions expressed in this paper are entirely those of the authors. They do not necessarily represent the view of the World Bank, its Executive Directors, or the countries they represent. 


\title{
Exchange Rate Overvaluation and Trade Protection:

\author{
Lessons from Experience
}

\author{
Howard J. Shatz \\ Center for International Development at Harvard University
}

and

\author{
David G. Tarr* \\ Development Research Group, The World Bank
}

* We would like to thank: Julian Berengaut, Dominique Desruelle and Paul Ross of the International Monetary Fund; Arup Banerji, Fred King, Kiyoshi Kodera, Lawrence Hinkle, Albert Martinez, Will Martin, Francis Ng and Maurice Schiff of the World Bank; numerous officials of the Government of Kazakhstan and seminar participants at the World Bank for helpful comments on earlier drafts. The views expressed are those of the authors and do not necessarily reflect those of the World Bank, its Executive Directors, any of its member governments, the International Monetary Fund, the Government of Kazakhstan or those acknowledged. 
. 


\section{Summary \\ Exchange Rate Overvaluation and Trade Protection: Lessons from Experience}

Despite a general trend toward more flexible exchange rate regimes, over half the countries in the world maintain fixed or managed exchange rates. There are clearly advantages and disadvantages of both fixed and flexible exchange rate systems and their variants, and we do not discuss their relative merits in this paper. Rather, we note that, as a practical matter, exchange rate management in many countries has resulted in overvaluation of the real exchange rate. Estimates suggest that about 25 percent of the countries for which we have data have overvalued exchange rates, with black market premiums from 10 percent to more than 100 percent.

Since governments are frequently confronted with the problems of external shocks and external trade deficits in the context of a fixed exchange rate regime, we found that a concise survey of the literature in terms understandable to policy-makers was needed. This paper presents worldwide experience regarding what has worked and what has not worked in response to these crises, and why. It also assess the consequences of overvaluation -- the frequent result or even cause of these crises -- the consequences of trying to defend an overvalued exchange rate, and the most appropriate policies for addressing an overvaluation.

Although as a group developing countries have progressively liberalized their trade regimes during the $1980 \mathrm{~s}$ and $1990 \mathrm{~s}$, some governments take actions to defend an exchange rate that are counter to their long run trade liberalization. That is, one classic pattern is to attempt to defend an overvalued exchange rate by protectionist trade policies. Experience shows that protection to defend an overvalued exchange rate will significantly retard the growth of the country and delay integration into the world trading community. In fact, an overvalued exchange rate is often the root cause of protection, and the country will be unable to return to the more liberal trade policies that allow growth and integration into the world trading community without exchange rate adjustment.

We briefly explain the benefits of an open trade regime, where we maintain that protectionist policies seriously retard growth and integration into the world trading community. We then provide a brief theoretical discussion of the many channels through which an overvalued exchange rate hurts the economy and growth. We argue that the vast majority of developing countries have downward price and wage rigidities and that with an external trade deficit they require some form of nominal exchange rate adjustment to restore external equilibrium. Next we present the cross-country econometric evidence; this shows that overvalued exchange rates lower economic growth. Subsequently we provide several specific country historical experiences (Chile, Argentina, Uruguay, Turkey, Malaysia) where overvalued exchange rates led to severe problems. In the case of Chile, the reversal of policies, from overvalued exchange rates 
and protection to competitive exchange rates and low protection., has paved the way for impressive growth. We also discuss the role of a competitive exchange rate policy in the impressive Korean growth experience. Given the significant rolle overvalued exchange rates have played in Sub-Saharan Africa, we discuss this experience separately and in some detail. We distinguish the CFA zone from the other countries and provide a case study of Ghana.

Worldwide experience has shown that defending the exchange rate has no medium-run benefits, since falling reserves will force devaluation eventually. It is better that the devaluation be accomplished without further debilitating losses in reserves and lost productivity due to import controls. Rather, the worldwide experience with devaluations shows that, post-devaluation, the exchange rate will reach a new equilibrium and that the equilibrium is strongly influenced by the policies of the central bank and the government.

Given that the new trade protection in response to balance of payments crises often leads to very diverse tariffs by sector and country, we discuss the adverse world experience with industrial policy that provides very diverse incentives to industries. 


\title{
Exchange Rate Overvaluation and Trade Protection:
}

\author{
Lessons from Experience
}

\author{
Howard J. Shatz and David G. Tarr \\ Harvard University and The World Bank
}

\section{Introduction}

Despite a general trend in the world toward more flexible exchange rate regimes, over half the countries in the world maintain fixed or managed exchange rates. ${ }^{1}$ Moreover, based on a fundamental measure of overvaluation, the black market premium, ${ }^{2}$ about 25 percent of the countries in the world have exchange rates that are overvalued by at least 10 percent, and 19 countries have premiums of more than 25 percent. In 10 countries, the black-market premium exceeds 100 percent, which implies that the exchange rate fails to serve its role in allocating foreign exchange. ${ }^{3}$

There are many reasons why countries maintain fixed exchange rate regimes: Their currencies may be linked to the currency of a partner or partners, e.g., the currencies of the CFA zone in Africa. The exchange rate may be used as a nominal anchor, as in the Southern Cone of Latin America in the early 1980s. Or the exchange rate regime may be employed as a means of regulating foreign trade, as in many of the former communist countries.

There are clearly advantages and disadvantages of both fixed and flexible exchange rate systems and their variants, and we do not discuss their relative merits in this paper. Rather, we note that, as a practical matter, exchange rate management in many countries in the world has resulted in overvaluation of the real exchange rate. Overvaluation can arise from several factors. Among them: It is the nature of cycles of international economic activity that from time to time countries are hit hard by external shocks. For developing countries, terms of trade shocks are often quite important, deriving typically from significant swings in energy or commodity prices. Financial

\footnotetext{
${ }^{1}$ As of the beginning of 1999 (the latest available data), the IMF (1999, Appendix I) reported arrangements for 185 countries. The exchange rate regimes can be divided into pegged ( 84 countries), floating ( 75 countries) and limited flexibility ( 26 countries). Of the 84 with pegged exchange rates, 37 have no separate legal tender, 8 use a currency board arrangement, 24 peg to another currency, and 15 to a composite of currencies. Of those floating, 27 maintain a managed float and 48 an independent float.

${ }^{2}$ The black market exchange rate is likely to be overly depreciated relative to an equilibrium long run real exchange rate since an actual real depreciation would increase the supply and reduce the demand for foreign exchange. See Ghei and Kamin (1999) for a detailed explanation and econometric evidence. ${ }^{3}$ See Global Currency Report (1999). 38 out of 160 countries had black market premiums of more than 10 percent at the end of 1998. Of these: 19 had premiums of more than 25 percent; 13 had premiums of more than 50 percent; and 10 countries had premiums of more than 100 percent. These latter 10 included Afghanistan, Algeria, Angola, Iraq, North Korea, Liberia, Libya, Myanmar, Sao Tome and Principe, and Somalia.
} 
crises are another important source of adverse external shocks, as financial crises adversely affect not only the countries involved, but also their trading partners. These external shocks may lead to overvaluation, as in Kazakhstan in 1999. Overvaluation may be the result of a systemic shift in the competitiveness of a linked currency, as in the case of the CFA zone in the late 1980s and early 1990s. In some cases inflation has eroded the competitiveness of the real exchange rate while the nominal exchange rate served as a nominal anchor (Southern Cone of Latin America in 1979-1982). Or a multiple exchange rate regime may be used as a means of exercising control over the foreign trade and exchange regime (e.g., Poland in the late 1980s). ${ }^{4}$

Although as a group developing countries have progressively liberalized their trade regimes during the 1980s and 1990s, some governments take actions to defend an exchange rate that are counter to their long run trade liberalization. That is, one classic pattern is to attempt to defend an overvalued exchange rate by protectionist trade policies. ${ }^{5}$ In the paper we present worldwide experience-what are the consequences of defending an overvalued exchange rate regime. Experience shows that protection to defend an overvalued exchange rate will significantly retard the medium to long run growth prospects of the country and delay integration into the world trading community. In fact, an overvalued exchange rate is often the root cause of protection, and the country will be unable to return to the more liberal trade policies that allow growth and integration into the world trading community without exchange rate adjustment. Moreover, a devaluation of the nominal exchange rate appears a necessary condition for achieving a large depreciation of the real exchange rate, as virtually all real devaluations (above 25-35 percent) have been accompanied by nominal devaluations (Ghei and Hinkle, 1999).

This paper is organized as follows. In the remainder of this section, we set the stage by discussing the recent experience of Kazakhstan and defining the key concepts of internal and external balance. In section II, we briefly explain the benefits of an open trade regime, where we maintain that protectionist policies seriously retard growth and integration into the world trading community. In section III we extensively treat the problems caused by an overvalued exchange rate. We begin with a theoretical discussion of many channels through which an overvalued exchange rate hurts the economy and growth. We then argue that the vast majority of developing countries have downward price and wage rigidities that require some form of nominal exchange rate adjustment to restore external equilibrium. Next we present the cross-country econometric evidence; this shows that overvalued exchange rates lower economic growth. Subsequently we provide several specific country historical experiences (Chile, Argentina, Uruguay, Turkey, Malaysia) where overvalued exchange rates led to severe problems. In the case of Chile, the reversal of policies, from overvalued exchange rates and protection to competitive exchange rates and low protection, has paved the way for impressive growth.

\footnotetext{
${ }^{4}$ See Tarr (1990, 1990a, 1994).

${ }^{5}$ Ghei and Pritchett (1999) call this the "import compression syndrome." Since devaluations (which reduce imports) are often accompanied by reductions of trade barriers (which increase imports), econometric evidence on the import reducing impact of devaluation has been weak. Ghei and Pritchett estimate that devaluations will reduce imports if import compression is properly accounted for.
} 
We also discuss the role of a competitive exchange rate policy in the impressive Korean growth experience. Given the significant role overvalued exchange rates have played in Sub-Saharan Africa, we discuss this experience separately and in some detail in section IV. Finally, in section V, given that the new trade protection in response to balance of payments crises often leads to very diverse tariffs by sector and country, we discuss the adverse world experience with industrial policy that provides very diverse incentives to industries.

\section{The Kazakhstan Experience}

The first draft of this paper was written in March 1999 due to the practical need to provide policy advice to Kazakhstan, which was in the middle of a crisis induced by external shocks. The authors found that a concise survey of the literature in terms understandable to policy-makers was needed. This paper should be useful as a basis of discussion in other countries when similar crises arise.

It is useful to discuss some of the specifics of the crisis in Kazakhstan in early 1999 as a motivation for the broader discussion to follow. Kazakhstan suffered several adverse external shocks in late 1998: it was hit by a fall in the international price of oil (its principal export product), the East Asian crisis and, most importantly, the Russian crisis and the Russian ruble devaluation. Given the lack of sufficient adjustment in the nominal exchange rate, the Kazakhstan tenge became significantly overvalued during early $1999 .^{6}$ Kazakhstan defended the tenge with bans on imports from Russia of many categories of foodstuffs, prohibitively high tariffs on imports of several categories of products from Kyrgyzstan and Uzbekistan, and threatened "antidumping" actions." These actions were potentially disastrous for Kazakh economic growth.

\footnotetext{
${ }^{6}$ While the tenge depreciated in real terms against the US dollar (by about 15 percent from July 1998 to January 1999) and many other Western currencies, it significantly appreciated in real terms against the Russia ruble (by about 68 percent from July 1998 to January 1999). Since Russia is the most important trading partner of Kazakhstan, the data show that a significant real appreciation of the tenge occurred. Taking all trading partners into account, the real exchange rate appreciated by about 19 percent between July and December of 1998. The overvaluation resulted in loss of competitiveness relative to partners in the region, especially Russia, and difficulty in defending the exchange rate. The precise quantitative extent of the overvaluation is beyond the scope of this note, but the data combined with the difficulties in defending the exchange rate clearly indicate that the tenge was overvalued.

${ }^{7}$ Most countries in the world apply at least some level of tariffs for protective purposes. Compared with tariffs in the customs code or "safeguard" actions, however, antidumping is an especially inappropriate manner of conducting international trade policy. The reason is that when import protection is applied, the costs and benefits to the nation should be evaluated. Evaluation of the relative costs and benefits is possible in a safeguard action or when the customs code is being changed. Antidumping, however, applies a tariff based on the practice of a foreign company or country and never asks the relevant question of whether application of the tariff is in the interest of the country. Moreover, exporters typically avoid antidumping duties by agreeing to raise the price of their exports, which hurts the importing country by having to pay higher prices for imports. See Finger $(1991,1996)$ for details and guidelines on how protection should be applied.
} 


\section{Box I}

\section{Update of Events: Devaluation and Liberalization in Kazakhstan}

On April 4, the Kazakh Government and the National Bank announced a free float of the tenge's exchange rate. They also announced an end to the highly protective trade measures introduced against Russia, Uzbekistan and Kyrgyzstan. The tenge first slumped to around 150 to the dollar, but later, by mid-April fluctuated between 110-120 to the dollar, and by August 1999 was holding around 132 tenge to the dollar, compared to the pre-devaluation 88 tenge to the dollar rate. The float was intended to boost Kazakh exports and to allow the National Bank to cease its costly efforts to support the tenge. These efforts had depleted hard currency and gold reserves to $\$ 1.7$ billion, down from $\$ 1.9$ billion in January.

Commenting on the government's actions, Prime Minister Nurlan Balgimbayev noted that due to devaluations among neighbor countries, Kazakhstan-produced goods had became uncompetitive. Kazakhstan industry suffered from that, enterprises stopped operating and unemployment increased. He indicated that foreign trade turnover of Kizakhstan was reduced by almost $9 \%$, or USD 1.3 billion with exports reduced by USD 1.25 billion. Kazakhstan had to undertake urgent measures caused by purely external factors and economic policies of neighbor countries. The trade protection was a response to those pressures.

He emphasized that henceforth the US dollar exchange rate will depend on demand and supply at the foreign exchange market. The National Bank of Kazakhstan (NBK) will not substantially intervene in this process. He said that until the announcement, the NBK was spending its gold and foreign currency reserves in order to support the exchange rate at a certain level, but that will not happen any longer. "We have no doubts regarding economic stability and our ability to manage the economic situation....NBK has significant gold and foreign currency reserves, but what is the reason to give the currency away and support an excessively expensive tenge?" Balgimbayev asked.

Regarding the highly protective trade measures against Russia, Kyrgyzstan and Uzbekistan, he noted that Kazakhstan has borders open for thousands of kilometers with those countries. Cheap goods from those countries easily compete with local producers and take foreign currency out of the country. It is practically impossible to close the borders, and it is also wrong from both economic and political points of view. "Russia and Central $A_{i}$ sian neighbors are our friends, and there is no reason to develop trade wars. From this point of view, the only solution is to introduce a floating exchange rate regime."

Source: Oxford Analytica, April 12, 1999 and August 17, 1999; Robert Lyle, Radio Free Europe, April, 1999.

Some Kazakh authorities feared that devaluation would lead to an unstable downward spiral of the exchange rate and possibly a Russia-style financial crisis. But the banking crisis in Russia was precipitated more by the government default on ruble denominated debt, which dramatically reduced the assets of many Russian banks overnight; these conditions were not present in Kazakhstan. Moreover, the worldwide experience, as well as recent experience in transition countries (for example, Ukraine, Moldova and Russia) has shown that defending the exchange rate has no medium-run benefits, since falling reserves will force devaluation eventually. It is better that the devaluation be accomplished without further debilitating losses in reserves and lost 
productivity due to import controls. Rather, the worldwide experience with devaluations shows that, post-devaluation, the exchange rate will reach a new equilibrium and that the equilibrium is strongly influenced by the policies of the central bank and the government. In April 1999, Kazakh authorities allowed a float of the exchange rate and reversed the protectionist measures.

\section{The Need to Restore Internal Balance}

When a country experiences a deficit in its trade balance, it is not in "external" balance. It follows from a national income accounting identity, however, that a trade deficit means that the country is spending more than its income. That is, the trade deficit allows the country to consume or spend beyond its income (or the value of what it is producing). When a country's expenditure does not equal its income, it is not in "internal" balance. These imbalances can severely impede country economic performance, and it is these imbalances that countries suffering from external shocks often face.

Although a nominal devaluation is designed to correct the problem of external balance, it will also be important to assure internal balance or the trade deficit may not be corrected by the nominal devaluation. For many developing countries the trade deficit reflects the government's fiscal deficit, which is often financed by monetary expansion. The monetary expansion in turn leads to inflation. The impact on the real exchange rate of a nominal devaluation in this environment is likely to be eroded by inflation, since high inflation tends to appreciate the real exchange rate, making elimination of the trade deficit problematical.

In general, monetary or fiscal policies will have to be combined with exchange rate policies to achieve both internal and external balance simultaneously. This is a special case of a more general principle of economics that multiple policy targets typically require multiple policy instruments. In this paper, however, we focus on the experience of countries that have limited the use of exchange rate adjustment as an economic policy instrument.

\section{The Benefits of an Open Trade Regime}

As we elaborate in the next section, a serious problem with exchange rate overvaluation is that it often leads to the imposition of high tariff and non-tariff barriers to international trade. Worldwide experience in the last 50 years, however, demonstrates the benefits of open trade regimes. The OECD countries brought trade barriers down through successive GATT/WTO negotiations and experienced sustained growth in trade and incomes. Many developing country governments initially felt differently and attempted to promote industrialization behind high protective barriers. But in the last ten years or so, the balance of opinion has shifted in these countries as well, as evidence accumulated that high rates of protection significantly depress economic development, 
and that open trade regimes are more conducive to growth. ${ }^{8}$ Moreover, virtually all recent development success stories have been based on strong industrial export growth and relatively low barriers to imports - Chile, Hong Kong, Malaysia, Mauritius, and Singapore - or continually falling barriers - the Republic of Korea and Taiwan (China). Industrial sectors in these economies not only have higher export growth but generate more employment as well; and trade reforms have usually been accompanied by increased flows of foreign investment.

An effective trade policy is central to the integration of developing countries into the international economic system and the growth that will generate. It provides links with international markets, and, together with the exchange rate, forms the transmission mechanism through which international trade affects domestic resource allocation, the efficient and competitive restructuring of industry and agriculture, access to new and diverse technologies, improved incentives to exporters, and reduction of smuggling, rentseeking ${ }^{9}$ and corruption in customs.

Tariff policy is the centerpiece of trade policy in a market: system. Tariffs are, with very few exceptions, the only acceptable policy tool for protection under the GATT/WTO. They are superior to alternative instruments of protection, such as nontariff barriers (NTBs) like quotas, licenses and technical barriers to trade (TBTs), because they are less likely to lead to rent seeking and corrupt practices, and because tariffs limit the exercise of domestic monopoly power where it exists whereas NTBs do not.

\section{The Problems of an Overvalued Exchange Rate}

Experience has shown that countries that attempt to maintain overvalued exchange rates significantly impede their growth in the medium to long term. Theory, cross-country statistical studies, and case histories all reinforce the basic findings that exchange rate overvaluation can reduce economic efficiency, misallocate resources, increase capital flight, and most perniciously, lead to exchange and trade controls.

\section{Problems Caused by an Overvalued Exchange Rate - Theory}

Theory suggests that there are many channels through which an overvalued exchange rate hurts the economy and growth: (1) it discriminates against exports. Since a significant portion of the costs of production is paid in domestic currency, the overvalued exchange rate results in a reduction of incentives and ability of exporters to compete in

\footnotetext{
${ }^{8}$ Sachs and Warner in a recent article (1995) have estimated that open economies have grown about one percent per year faster than closed economies, and that the difference is greater among developing countries. For a review of the extensive literature on the link between open trade regimes and economic growth see Edwards (1993). See also Dollar (1992).

${ }^{9}$ Rent-seeking refers to the expenditure of resources to achieve a favorable regulatory intervention by government. In this context, it refers to lobbying of government officials (including bribes) to achieve protection from international competition. It is generally rather inefficient since resources that could be used on productive activities are diverted to influence government decisions regarding protection.
} 
foreign markets. This chokes foreign exchange receipts and damages a country's ability to purchase the imports needed for economic activity; (2) an overvalued exchange rate means that import-competing industries are faced with increased pressure from foreign companies, resulting in increased calls for protection against imports from industrial and agricultural lobbies. The political pressures for protection eventually prove to be overwhelming and governments yield to lobbying and offer increased tariffs on imports. This closes the economy to international competition, reduces access to needed imported inputs and technology, and growth falls as a result. Devaluation serves the dual purpose of uniformly protecting import competing industries and increasing the incentives to exporters; (3) another way that overvalued exchange rates impede growth is that productivity advances are less rapid. This is because the export sectors and the import competing sectors are disadvantaged by an overvalued exchange rate, and it is in these sectors that productivity advances are often most rapid (Cottani, Cavallo and Khan, 1990); (4) overvaluation induces capital flight among domestic citizens anticipating a devaluation. As a result, less foreign exchange is available for needed imports; (5) foreign exchange may become rationed and allocated inefficiently by the government; and finally, (6) efforts to defend an overvalued exchange rate through very tight monetary policy can plunge the country into severe recession. This last concern was very relevant in Kazakhstan before the move to the free float, since monetary and fiscal policies were under too much pressure to defend the exchange rate, risking adverse impacts on investment and output.

\section{The Problems with "Automatic" Adjustment Mechanisms to an Overvalued Exchange Rate}

Unless the central bank takes offsetting action, a trade deficit will result in a decline in the domestic money supply. Thus, one response to an overvalued exchange rate is to hold the nominal exchange rate fixed and assume that domestic prices and wages will fall to help bring tradable goods prices back to internationally competitive levels. This is the mechanism known as the specie flow mechanism described by David Hume in the $18^{\text {th }}$ century. The problem with this strategy is that prices and wages tend to be sufficiently inflexible downward in most modern economies that sustained and substantial periods of unemployment must be endured if the strategy is to have a chance of being successful. Most countries are unwilling to endure these high costs. ${ }^{10}$ Some prominent examples are provided here. Further insight is provided in the section below on "case studies of the effects of overvaluation."

England 1924. In October 1924, England embarked on a policy of increasing the value of sterling relative to gold to its pre-World War I level. This amounted to a real appreciation of 10 percent and required export industries to reduce their prices if they wanted to stay internationally competitive. Furthermore, in order to avoid trade and payments imbalances, the Bank of England increased interest rates and restricted lending abroad. John Maynard Keynes (1925 in 1963 edition, pp. 247 and 256-257) described the difficulties of this strategy:

\footnotetext{
${ }^{10}$ See Sachs and Larrain (1999) for a further discussion.
} 
Our export industries are suffering because they are the first to be asked to accept the 10 per cent reduction ... Our problem is to reduce money wages and, through them, the cost of living, with the idea that, when the circle is complete, real wages will be as high, or nearly as high, as before. By what modus operandi does credit restriction attain this result? In no other way than by the deliberate intensification of unemployment... . (italics original).

CFA Zone. In more recent times, the CFA zone countries in Africa attempted such internal adjustment during the period of their real overvaluation, 1986 to 1994 (Clément et al., 1996, and Nashashibi and Bazzoni, 1994). This resulted in disastrous consequences for the CFA countries as the economic contractions in some of them were comparable to the Great Depression of the United States. (See table 1 below for data on the two largest CFA countries.) Large increases in poverty and other economic problems ensued (see Devarajan and Hinkle, 1994, and further discussion in section IV). ${ }^{11}$

\section{Table 1. Comparing Great Depressions: Cameroon, Côte d'Ivoire and the United States}

All numbers are the percentage decline in per capita GDP.

\begin{tabular}{|l|c|c|c|}
\hline \multicolumn{1}{|c|}{ Measure of Output Decline $\backslash$ Country } & Cameroon & Côte d'Ivoire & United States \\
\hline Purchasing Power Parity ${ }^{\prime}$ & 31.4 & 29.1 & N.A. ${ }^{\prime}$ \\
\hline $\begin{array}{l}\text { Purchasing Power Parity with Terms of } \\
\text { Trade adjustment }{ }^{\mathbf{a}}\end{array}$ & 38.5 & 34.5 & N.A. \\
\hline Market Prices ${ }^{\mathrm{b} /}$ & 41.5 & 18.8 & 30.9 \\
\hline
\end{tabular}

${ }^{\prime}$ Author's calculations for 1986-1992 from the Penn World Table Mark 5.6, described in Summers and Heston (1991) and available on the website: http://pwt.econ.upenn.edu. Post-1992 data are unavailable.

b/ Authors' calculations from the peak to the trough of the depression. This is 1986-1994 for Cameroon and Côte d'Ivoire, and 1929-1933 for the United States. Data are from the World Bank (1999) and U.S. Bureau of the Census (1975).

cl Not Available.

Governments tried especially hard to rein in wage costs, but without success. In fact, wages actually rose relative to GDP. In addition, the high real exchange rate hurt the export and formal manufacturing sectors, undermining the domestic tax base and widening budget deficits. Furthermore, the economic slowdown called for by internal adjustment caused a change in the composition of imports, to lower-value items, and increased the level of informal imports so that tariff revenues also fell. This meant that at a time when internal adjustment called for the CFA zone governments to decrease their fiscal deficits, these deficits actually increased since the governments could not reduce

\footnotetext{
${ }^{11}$ For example, the incidence of poverty doubled in Côte d'Ivoire from 30 percent to 60 percent between 1985 and 1992.
} 
their spending by as much as their revenue fell. As noted below, the CFA franc devaluation of 1994 - external adjustment - was followed by a return of economic growth and increased trade.

The CFA zone experience also casts doubt on the claim that countries should avoid devaluations in order to retain international investors. The zone certainly had stable prices and exchange rates, but its failure to solve the problems brought on by the overvalued real exchange rate decreased its attractiveness to foreign investors substantially. Capital flight increased in anticipation of an eventual devaluation (Clément et al.).

Chile 1999. Faced with weak demand from Asia and falling prices for its principal commodity export, copper, Chile saw its current account deficit widen and its currency come under attack. At first the central bank raised interest rates, but the high interest rates cut domestic demand on top of the decline in demand for exports, and plunged the country into its worst recession in 16 years and its highest unemployment rate in 10 years. On September 2, the Central Bank allowed the currency to float, suspending its formal commitment to intervene in the foreign exchange markets to keep the peso within a band. The currency immediately fell by a small step, from 519.35 to the dollar to 523.25 to the dollar (Torres, 1999).

\section{Real Exchange Rate Overvaluation and Cross-Country Economic Performance}

Cottani, Cavallo, and Khan (1990) investigated the effects of real exchange rate misalignment and variability on the economic performance of 24 developing countries from 1960-1983. They found that exchange rate misalignment was strongly related to low growth of per capita GDP. Furthermore, misalignment was also related to low productivity. Capital did not go to the companies or sectors that could make the best use of it. Finally, misalignment was also related to slow export growth and slow agricultural growth.

A study of growth in 12 countries from 1965-1985 (Edwards, 1988 and 1989), reinforced these findings. ${ }^{12}$ The greater the misalignment, the lower the growth during the period. Furthermore, exchange controls and trade impediments, proxied by the black market exchange rate premium, were negatively related to growth. ${ }^{13}$

In a study of economic growth in 18 Latin American countries between 1950 and 1980, Cardoso and Fishlow (1989) showed that growth was very uneven among the

\footnotetext{
${ }^{12}$ The 12 are Brazil, Colombia, El Salvador, Greece, India, Israel, Malaysia, Philippines, South Africa, Sri Lanka, Thailand, and Yugoslavia.

${ }^{13}$ Faini and de Melo (1990) took a somewhat dimmer view of the impact of the real exchange rate on economic performance. They found a positive, but usually not significant, relationship between devaluations and the improvement of the trade balance for 49 developing countries between 1965 and 1985. However, they also found for a smaller sample, different because of data availability, that a depreciated real exchange rate promoted investment. Furthermore, they found that for adjusting countries during the $1980 \mathrm{~s}$, the higher prices of imported intermediates brought about by devaluations were not important determinants of depressed investment.
} 
countries of the region. They found that the most important determinant of Latin American country growth rates in these years was export performance and access to imports. While they did not discuss the real exchange rate, their findings are valuable for showing the importance of the trade channels through which the exchange rate affects country economic performance. Exports were important not only because competing in international markets induced efficiency, but also because export earnings could avert recurrent stabilization crises. Imports contributed to growth because the region's industrialization strategy demanded imported inputs. Countries forced to limit their imports performed less well.

\section{Case Studies of the Effects of Overvaluation}

The economic histories of developing countries that followed a classic importsubstituting industrialization strategy after World War II provide good illustrations of the negative effects of an overvalued exchange rate combined with trade controls. Latin America, more than any other region, followed this strategy but was not alone. We select illustrative episodes from Argentina, Chile, Uruguay, and Turkey.

Argentina, Chile, and Uruguay. Argentina, Chile, and Uruguay all followed import-substituting industrialization policies that led to a bias against exports, extremely uneven rates of trade protection across sectors, and controlled financial systems. They also experienced recurrent balance-of-payments crises and slow growth (Corbo, de Melo, and Tybout, 1986). By the early 1970s, all three had accelerating inflation, bottlenecks in production, slow expori growth, and balance of payments difficulties (Corbo and de Melo, 1987).

In response, they went through two phases of stabilization and reform, one in the mid-1970s and the other from 1979-1982. The second phase is most applicable to judging the effects of an overvalued exchange rate and import controls on economic performance.

In the second phase, all three countries used a nominal exchange rate anchor to halt inflation. The exchange rate appreciated, and when it became apparent that the nominal rate could not be sustained, capital flight resulted. In Uruguay and Argentina, where there were no capital controls, major capital outflows occurred. In Chile, where there were capital controls, people engaged in capital flight by buying imported consumer durables. This capital flight occurred in all three countries well before the onset of the debt crisis in 1982.

Other problems resulted. Profitability fell in the tradable goods sectors. In Argentina, which remained quite restrictive to imports throughout, the gross margins of exporting businesses were hurt much more than those of import-competing businesses. In Uruguay, the rate of growth of nontraditional exports fell sharply from 1979-1981. And in Chile, the leading growth sectors during the period became construction, internal trade, and financial services, all nontradables, even though reforms during the 1975-1979 period had reduced the bias against exports significantly by June 1979. 
Chile: The Aftermath. Chile is now well known for its economic success. Its average annual rate of growth of real GDP has been more than $7 \%$ since 1984 . Its policies following a crisis of 1982-1983 are instructive.

It is true that Chile experienced high rates of growth in the late 1970s. This followed a deep contraction in 1974-1975, and came as a result of a number of deregulation and reform measures, including instituting a uniform $10 \%$ tariff on all goods except automobiles. However, as alluded to above, inflation persisted, hurting the reforms, and Chile fought back with a fixed rate as a nominal anchor in 1979. Combined with other policies, this at first led to large external borrowings, most of which were at variable interest rates. In the early $1980 \mathrm{~s}$, the external financing dried up as confidence in the sustainability of the exchange rate ebbed. Making matters worse, Chile experienced a deterioration in the terms of trade, and then foreign interest rates rose, further hurting the Chilean financial and business sectors. In 1982-1983 Chile experienced its worst depression since the 1930s, with real GDP falling 15 percent.

During and immediately after the recession, Chile tried a number of policies, including an increase in tariff rates to switch domestic spending to domestic products. In June 1982, the government abandoned the fixed rate and eliminated compulsory wage indexation, and initiated a series of nominal devaluations. For a short time, Chile allowed the exchange rate to float (Corbo and Fischer, 1994). However, Chile then followed an erratic policy, implementing five different exchange rate regimes (Labán and Larraín, 1995).

In 1985 the government embarked on the strategy it maintains to this day, specifically, an export-oriented structural adjustment. This included steady devaluations and a staged lowering of uniform tariffs from $35 \%$ in 1984 to $11 \%$ by 1991 . Importantly, the new nominal exchange rate system featured a crawling band, and policy makers intended to use it to maintain the international competitiveness of Chilean exports (Dornbusch and Edwards, 1994). In fact, though they used the nominal rate as the policy variable, they focused on the real exchange rate, adjusting the nominal rate for the differential between domestic and foreign inflation. Using an index of 100 as the value of the real rate in 1977 , the real exchange rate appreciated to 84.5 in 1981, then fell to 118.2 in 1984, and then following the introduction of the new policy, depreciated to 145.2 in 1985. It continued depreciating to 180.1 in 1990 (Corbo and Fischer). In 1998 the Chilean legislature approved further lowering of the uniform tariff to $6 \%$ in stages, and in late 1999 Chile abandoned the exchange-rate band system for a float.

The improved incentives to exporters from the reduction in the import tariff and the devaluation led to an expansion of nontraditional exports (10.5\% a year from 1985 1989 ) and efficient import substitution. Macroeconomic stabilization, tax reform, and cuts in government spending combined to promote savings and investment. And privatization of state-owned firms, rehabilitation of the financial sector through recapitalization, and the strengthening of bank regulation combined to spur private business activity. 
Turkey. Three episodes from the post-WWII history of 'Turkey, recounted in Krueger (1995), also illustrate the problems created by an overvalued exchange rate combined with import restrictions.

Like the Latin American countries, Turkey followed an import-substituting industrialization growth strategy. Starting in 1953, export growth ceased for a number of reasons and inflation accelerated. Inflation combined with a fixed nominal exchange rate meant a strengthening real exchange rate and a bias against exports. Foreign exchange became scarce, so the country started import licensing in 1954. By 1957, export earnings were falling and imports were severely restricted, damaging domestic economic activity. By 1958, Turkey could not finance imports and it appeared that the country would not even be able to obtain gasoline for trucks to move that year's harvest to ports. In response, Turkey adopted an IMF stabilization plan featuring devaluation, import liberalization, and fiscal and monetary restraint. Real GDP had been declining, but started growing immediately in response to the availability of imports. Inflation fell and export earnings started to rise again. Turkey was among the most rapidly growing developing countries of the $1960 \mathrm{~s}$.

In the late 1960s, however, Turkey's exchange rate again became overvalued due to moderate inflation throughout the decade (five to 10 percent annually), combined with a fixed nominal exchange rate. The high demand for imports combined with the bias against exports caused foreign exchange to become scarce. The resulting problems getting imports caused a slowdown in both production and real investment. The country responded in 1970 with a nominal devaluation, and the result was extremely rapid export growth. Turkey then experienced rapid economic growth through 1975.

The third Turkish episode occurred in the late 1970s. Large fiscal deficits, a failure to change the internal price of oil following the 1973 oil shock, and an overvalued exchange rate, made worse by extremely high inflation, spurred this third crisis. Once again, the country ended up with severely constrained imports, falling real output, and falling income.

\section{Exchange Rates and Economic Performance in East Asia}

Despite the recent Asia crisis, the record of economic development in Asia remains enviable. A large reason for rapid Asian growth was exchange rate management (Roemer, 1994). Successful Asian countries kept their nominal rates close to marketclearing levels, exhibiting low or no parallel-market premiums. Importantly, this flexibility allowed their real exchange rates to remain constant or depreciate gradually, maintaining real returns to exporters over long periods. In some cases, policy makers carried out nominal exchange rate devaluations with the real exchange rate in mind. Oilexporter Indonesia devalued substantially in 1978 even though export earnings were rising, because policy makers were concerned that a real exchange rate appreciation during the previous six years was hurting non-oil sectors. When oil prices fell in 1983 , 
export earnings were not as badly hurt as in other oil-exporting countries, and further devaluations from 1983 to 1986 encouraged a non-oil export boom (Lewis and McPherson, 1994). We present two more detailed cases, Korea and Malaysia.

Korea. Korea is often viewed as an example of a country that grew despite (or because of interventionist government policies. While the actual effect of government policies is hotly debated, one fact is clear - Korea avoided overvaluation of its exchange rate to encourage its exporters. Thus, many regard its exchange rate management policy as a key to Korea's successful long-term economic performance (see Nam, 1995). Before 1960, the government kept the nominal exchange rate fixed with only small adjustments, resulting in overvaluation and balance-of-payments problems. These problems forced the government to use multiple exchange rates, import licensing, and high and diverse tariffs. In this way, Korea was a typical inward-looking developing country.

Starting in the early 1960 s, however, Korea shifted its strategy to export orientation. It unified its exchange rate in 1961 and devalued from 130 won to the dollar to 255 won to the dollar in May 1964. With Korean inflation much higher than the levels of Korean trading partners, Korea avoided overvaluation by gradually devaluing the nominal rate, reaching 893 to the dollar at the end of $1985 .{ }^{14}$ Only during the second half of the $1970 \mathrm{~s}$, in an effort to dampen domestic inflation, did policy makers fix the nominal rate at 484 won to the dollar. The fixed-rate policy, along with a number of other factors, resulted in overvaluation and a stagnation in growth and export performance. These economic problems led policymakers to devalue the won in 1980 to 580 to the dollar, the first devaluation since 1974. Afterwards, they allowed the won to depreciate gradually through the end of 1985.

The most telling result of Korea's policy of exchange rate flexibility is that from 1953 to 1960 , per capita GDP measured in constant purchasing power parity dollars grew at an average annual rate of 1.8 percent. From 1960 to 1991, it grew at an average annual rate of 6.9 percent, from $\$ 904$ to $\$ 7,251$. Analyzing data for 126 countries for the period 1960 to 1992, Pritchett (1997) showed that Korea had the highest growth rate of real per capita GDP measured in purchasing power parity dollars. ${ }^{15}$ Nam reported that in addition, exports rose even more rapidly than GNP. The ratio of exports to GNP was 2.4 percent in 1962, and 25.6 percent in 1991. Manufactured goods as a share of exports rose from 27 percent in 1962 to 95.4 percent in 1991.

Malaysia. In some ways, the problems faced by Malaysia in the early $1980 \mathrm{~s}$ were similar to those of Africa, to be described in section IV. Malaysia faced decreases in

\footnotetext{
${ }^{14}$ The nominal rate appreciated once again between 1986 and 1989, and then depreciated through 1991, the end of the period under study in Nam.

${ }^{15}$ Using real GNP data from the Bank of Korea, Nam reported an aggregate growth rate of 3.6 percent annually in the 1950s, and 10.6 percent annually from 1962 to 1991. World Bank (1999) showed an average annual growth rate of real aggregate GDP of 8.6 percent from 1962 to 1991 , but did not have data for the 1950s. The per capita GDP figures cited in the text and by Pritchett are from the Penn World Tables Mark 5.6 (Summers and Heston, 1991). We downloaded the data from the University of Toronto, http://datacentre.chass.utoronto.ca/pwt/index.html.
} 
world commodity prices, a current account deficit, and an overvalued real exchange rate. The country had a much more successful adjustment, however, and embarked on a decade of rapid growth.

As recounted in Demery and Demery (1992), Malaysia had high levels of economic growth and rapid rates of growth of manufacturing exports between 1968 and 1984, but was a major natural resources exporter as well. Key commodity exports included tin, rubber, petroleum, natural gas, and palm oil. Commodity and oil prices boomed in 1979 and 1980, and the government expanded spending. These prices started declining significantly in 1981. The terms of trade reversals cost the country real income amounting to seven percent of GDP in 1981 and three percent in 1982. However, expecting the reversals to be temporary, the government maintained its fiscal expansion, relying on foreign borrowing to finance growing government deficits. The large inflows of debt finance, combined with government spending tilted towards the nontradables sectors, resulted in an appreciation of the real exchange rate.

Starting in 1984, the Malaysian government embarked on an adjustment program. It cut government spending to reduce the deficit. ${ }^{16}$ To restore external competitiveness and profitability in tradables, it depreciated the nominal exchange rate and reduced external borrowing. Combined with lower domestic inflation, these policies led to a real depreciation between 1985 and 1987 of just under 30 percent.

The change in the real exchange rate, along with the other adjustment policies, had several beneficial effects. The current account returned to surplus in 1986 and 1987 and resources started to move back to the tradables sectors. ${ }^{17}$ The adjustment also restored growth. According to World Bank data (World Bank, 1999), aggregate real GDP growth averaged 8.3 percent annually from 1987 to 1991 , well above the rates before the adjustment. ${ }^{18}$ And for the whole decade 1987 to 1996 aggregate real growth averaged 8.5 percent.

\footnotetext{
${ }^{16}$ Lower tax revenues resulted in the deficit rising again in 1986 and 1987 , though the government financed this mostly with domestic borrowing. Foreign borrowing was actually negative in 1987. Another result of the government's expenditure reduction policies was that private consumption and investment fell from 1984 to 1987 . This kept demand for imports flat while the level of exports rose, helping bring the current account back into balance.

${ }^{17}$ Between 1979 and 1984, these sectors (agriculture, mining, and manufacturing) fell from 56 percent of GDP to 52 percent, but recovered to 54 percent in 1987.

${ }_{18}$ Although GDP grew by 6.8 percent annually between 1980 and 1984, Demery and Demery attribute this largely to government spending, which was unsustainable, given the current arcount deficit, the growth of government debt, and terms of trade reversals. During 1985 real GDP fell by 1.1 percent, and then rose by 1.2 percent the next year.
} 


\section{Exchange Rates and Economic Performance in Sub-Saharan Africa}

\section{Introduction}

While the countries of post-colonial Africa represent a remarkable diversity of people and geography, their economic policies leading up to the 1980s bore a striking similarity (Foroutan, 1997). They established tight control over economic activity using import and export quotas and prohibitions, price controls, foreign exchange controls, interest rate ceilings, state-owned enterprises, and marketing monopolies. This produced a layering of policies with a strong bias against trade (Nash, 1997). By the early 1980s, many countries faced balance of payments crises and economic decline.

Terms of trade shocks played a large role in triggering these problems (Bouton, Jones, and Kiguel, 1994). Commodity booms in the second half of the 1970s led to higher government revenues and the rapid expansion of government spending. In the early and mid-1980s, commodity prices fell, but governments did not adjust. Continuing to spend, they financed their mounting deficits with external debt and inflation. For example, Madagascar's budget deficit grew from four percent of GDP in 1978 to 17 percent in 1982, inducing inflation. Kenya's foreign debt, very low at the beginning of the $1970 \mathrm{~s}$, reached 50 percent of GDP a decade later. The foreign borrowing appreciated the equilibrium real exchange rate. Inflation and a lack of adjustment of nominal exchange rates led to significantly overvalued real exchange rates throughout Africa.

In response to the real appreciation, countries imposed exchange controls and import restrictions rather than devalue, and this triggered a downward spiral. The overvalued rate reduced incentives for exporters and the trade balance worsened, forcing officials to impose even tighter restrictions. Many countries ended up with negative growth. Ghana's real per capita income, for example, declined 30 percent between 1970 and 1983, and real export earnings declined 52 percent. Throughout Africa, real per capita income fell by 15 percent between 1977 and 1985 and export performance collapsed from about 10 percent annual growth in the early 1970 s to declines in the early 1980 s (Jones and Kiguel, 1994). These problems resulted in a period of painful adjustment programs.

The valuation of the real exchange rate proved a key to successful reforms. Comparing three areas of policy - exchange rate, fiscal, and monetary - Bouton, Jones, and Kiguel conclude that exchange rate reforms had the biggest effect on growth.

\section{The Exchange Rate: Cross-Country Studies}

Any analysis of the continent's experience must differentiate between the CFA franc countries, which peg their currency to the French franc, and the countries of the rest of Sub-Saharan Africa, which independently determine their exchange rate policies. ${ }^{19}$

\footnotetext{
${ }^{19}$ The West and Central African Monetary Unions, which together with Comoros, form the CFA (Communauté Financière Africaine) zone have convertible currencies pegged at a fixed rate against the
} 
The growth records of these two groups are very different, as shown in the following table. The resumption of aggregate growth for each group coincided with real exchange rate adjustments.

Table 2: Real Growth Rates in Africa, 1981-1995 (annual averages)

\begin{tabular}{|c|c|c|c|}
\hline Country Group & $1981-1985$ & $1986-1993$ & $1994-1995$ \\
\hline Non-CFA Zone Countries & & & \\
\hline GDP Growth & 0.4 & 4.4 & 3.0 \\
\hline Per-Capita GDP Growth & -2.5 & 2.1 & -0.2 \\
\hline CFA Zone Countries & & & \\
\hline GDP Growth & 4.3 & -0.4 & 2.8 \\
\hline Per-Capita GDP Growth & 0.6 & -3.2 & -0.8 \\
\hline
\end{tabular}

Source: Klau (1998)

Outside of the CFA zone, most Sub-Saharan African currencies experienced large real appreciations in the 1970 s and early 1980 s, estimated at about 44 percent on average. The CFA-zone overvaluations started a bit later, in the mid-1980s.

There is strong evidence that the overvaluation of real exchange rates contributed a great deal towards Africa's poor economic performance. Ghura and Grennes (1993) analyzed the relationship between the real exchange rate and macroeconomic performance in 33 Sub-Saharan African countries between 1972 and 1987. They found that misalignment, or overvaluation, was associated with lower levels of growth of real GDP per capita, lower levels of exports, lower levels of imports, lower levels of investment, and lower levels of savings, even when correcting for other causes.

Klau (1998) showed that the CFA franc overvaluation of the late 1980s and early 1990 s was one of the principal causes of output decline in those countries. In both CFA zone and non-CFA zone countries, he showed that real devaluations are associated with short-run and long-run improvements in economic activity, as suggested in the table.

Real devaluations are also associated with improvements in African export performance. Sekkat and Varoudakis (1998) analyzed the real exchange rate and manufactured exports in three sectors in 11 African countries from 1970 to 1992. They found that an overvaluation was negatively associated with exposts in all three sectors, textile products, chemical products, and metal products, for the non-CFA zone countries.

The next section presents case studies of Ghana, one of the non-CFA reformers, and the CFA countries as a group.

French franc. Their monetary arrangements help guard against large losses of reserves and shortages of foreign exchange. Membership in the zone has changed somewhat over time, but in general has included Benin, Burkina Faso, Cameroon, Central African Republic, Chad, Congo, Cornoros, Côte d'Ivoire, Equatorial Guinea, Gabon, Mali, Niger, Senegal, and Togo. 


\section{Case Studies of Reform and Adjustment}

Ghana. Ghana's reform record has been one of the better in Africa, as detailed in Nowak, Basanti, Horvath, Kochhar, and Prem (1996). Part of this record included the transformation of the currency, the cedi, from one of the most overvalued in the world to a convertible currency by 1992 . Ghana also moved its budget towards balance and liberalized its trade policies, and began to see significantly improved growth.

Reforms, known as the Economic Recovery Program (ERP), took place in two phases, 1983 to 1986 and then 1987 to 1991. In the period leading up to the program, 1978 to 1983 , real GDP fell at an average annual rate of 1.6 percent, and gross investment, merchandise exports, and merchandise imports were all about five percent of GDP. One sign of the problems of the economy was the currency's black-market premium, the exchange rate in informal markets compared to the official rate. It finished the period at 223 percent in 1983, after exceeding 500 percent earlier in the 1980 s (see Sekkat and Varoudakis, 1998).

The first phase of reforms aimed at stabilization, along with major changes to the trade and exchange rate rules. Ghana lowered the level and dispersion of average tariff rates, eliminated quantitative restrictions, and corrected the exchange rate. Inflation fell from almost 123 percent in the years before the program, to 24.6 percent during the first period of the program. Real GDP started growing again at an average annual rate of 3.6 percent, and gross investment rose to 7.5 percent of GDP. Exports and imports both rose above eight percent of GDP, through exports remained concentrated in cocoa.

The second period of reforms attempted further structural and institutional changes. The unification of foreign exchange markets in 1990 brought an end to the black market premium, which measured 0.4 percent in 1991. GDP grew even faster in the second period at an average annual rate of 4.8 percent. Gross investment rose to 14.7 percent of GDP, while merchandise exports and imports rose to 15.5 percent and 19.1 percent respectively. Exports rose despite a decline in the terms of trade. Nowak et al. find econometric evidence that the elimination of the exchange rate overvaluation helped improve both investment and growth.

Poverty fell between 1987-88 and 1991-92, especially in rural areas, partly due to increased trade (World Bank, 1995). Overall, the incidence of poverty decreased from 36.9 percent to 31.5 percent. Rural areas account for two-thirds of Ghana's population, and rural poverty fell from 41.9 percent to 33.9 percent. Poverty increased in Accra, the capital, from 8.5 percent to 23.0 percent, but fell in other urban areas, so that urban poverty actually fell from 27.4 percent to 26.5 percent. Decreases in poverty were especially sharp for female-headed households and for non-farm rural households, but were present in nearly all population groups.

Economic growth caused most of the reduction in poverty, with the bulk of income growth in non-farm self-employment, especially wholesale and retail trade. Part of the increased activity in domestic trade came from a rebound from depressed levels 
before the start of the ERP. However, the other was from the surge in both imports and exports, a direct result of the ERP and its exchange rate and other. reforms.

While Ghana was a successful reformer on many dimensions, its experience also illustrates the difficulties of reform in a highly distorted economy with a history of government intervention. Not all reforms remained in place. In 1992, with a new constitution in April and elections in November and December, the government gave large increases in wages and benefits, throwing the budget far out of balance and increasing the rate of inflation. Private saving and investment subsequently declined as well (see Nowak et al.).

Despite those problems, Ghana has benefited from its reforms. GDP growth has remained strong, averaging more than four percent each year frorn 1995 to 1997 , and the black-market premium has stayed almost non-existent.

The CFA Zone Countries. Background and Devaluation. Until the second half of the 1980s, the countries of the CFA zone experienced stable and positive economic performance (Elbadawi and Majd, 1996). For example, their average annual real GDP growth rate from 1973 to 1981 was 5.7 percent, compared to an average of 2.8 percent for 18 non-CFA Sub-Saharan African countries. In addition, their annual average export growth rate was 7 percent, compared to 1.2 percent, while their irvestment and savings rates were about equal with those of the rest of Africa. This better economic performance was partly due to the exchange rate link, at 50 CFA francs to one French franc, at a time when the French franc was depreciating against the U.S. dollar and the terms of trade were relatively favorable on average.

However, the economic performance of the CFA zone countries began to deteriorate in the mid-1980s for two reasons, the appreciation of the French franc and a series of primary-commodity price shocks (Azam and Devarajan, 1997). Devarajan (1997) shows that for most of the CFA countries, these changes brought about real exchange rate overvaluations. Studying 12 countries $^{20}$ he found an average overvaluation of 31 percent in 1993 on the eve of the devaluation, with Cameroon's real exchange rate the most overvalued (78 percent) and Chad's real rate the only undervalued one. Eight of the 12 had overvaluations of 20 percent or more. Making matters worse, other African countries were devaluing during the $1980 \mathrm{~s}$, contributing to the overvaluation of the real rates of the CFA zone countries compared to those of their export competitors.

Because of the overvaluations and mounting structural problems, such as rigidly high wages, economic performance started to deteriorate. The zone saw no economic growth between 1986 and 1994 when other Sub-Saharan African countries were growing at 2.5 percent annually (Clément, 1994). In fact, as mentioned above, for some of the countries there was an output contraction comparable to the Great Depression in the United States.

\footnotetext{
${ }^{20}$ Countries analyzed included Benin, Burkina Faso, Cameroon, Central African Republic, Chad, Congo,
} Côte d'Ivoire, Gabon, Mali, Niger, Senegal, and Togo. 
There were a large number of other ill effects from the period of overvaluation in the CFA zone. A number of countries suffered large increases in poverty (Devarajan and Hinkle, 1994). For example, the incidence of poverty doubled in Côte d'Ivoire from 30 percent to 60 percent between 1985 and 1992. Devarajan and Hinkle also note that banking systems in a number of countries became insolvent or illiquid as a result of the private sector's inability to repay debts, government and public enterprise arrears, and capital flight. Export earnings collapsed in response to the adverse terms of trade shocks and the overvaluation of the real exchange rate. The contractionary macroeconomic policies adopted by most of the CFA countries reduced import levels and inflation remained low; but budget and external deficits rose. The fixed nominal rate and various policy-induced rigidities in domestic prices - particularly in wages and non-tradable goods prices - meant adjustment had to come through reduced employment, output, and growth. $^{21}$

Analyzing data through the end of the 1980s, Elbadawi and Majd showed the effects on CFA economic performance by comparing average annual changes in various economic aggregates for the CFA countries with other sub-Saharan African countries. The CFA countries had real GDP growth of 2.9 percent between 1982 and 1985, but 0.4 percent from 1986 to 1989 . The other African countries had -0.2 percent growth in the first period, when they were starting to adjust, and 2.8 percent growth in the second period. Export growth fell from 3.4 percent to -4.4 percent for the CFA countries, but rose from 0.6 percent to 4.4 percent for the other African countries. Investment fell in both groups, while savings rose only in the non-CFA group. Elbadawi and Majd showed statistically that CFA membership, and by implication the high real exchange rate level, was partly to blame for the poor economic performance of the late 1980 s.

Constrained by their fixed exchange rates, at least two of the CFA zone countries tried to undergo so-called mock devaluations, with subsidies to exports and increases in import tariff rates. In Côte d'Ivoire, the scheme collapsed after a short trial because of administrative difficulties, inability to give the export subsidy plan a sufficient budget, and lack of support by the government. In Senegal, administration proved difficult, and the scheme encouraged overinvoicing by exporters and smuggling and underinvoicing by importers. The plan also proved costly to the budget, as tariffs were already high and the increases could not generate much more revenue.

Finally, the countries held a "maxi-devaluation" on January 12, 1994, changing their rates to the French franc from 50 to one to 100 to one. ${ }^{22}$

\footnotetext{
${ }^{21}$ For example, both Senegal and Côte d'Ivoire had rigid labor laws that kept wages high throughout the pre-devaluation period (Foroutan, 1997). Clément (1994) noted that throughout the CFA zone, rising wage costs contributed to substantial drops in public enterprise profitability, expanding the public sector financing requirement. Extensive controls over both producer prices and retail prices, particularly nontradable goods prices, also added to the price rigidities in many countries.

${ }^{22}$ The Western and Central African Monetary Unions (comprising Benin, Burkina Faso, Cameroon, CAR, Chad, Congo, Côte d'Ivoire, Equatorial Guinea, Gabon, Mali, Niger, Senegal, and Togo) changed their rates from 50 CFA francs to one French franc to 100 CFA francs to one French franc. Comoros changed its rate from 50 Comoros francs to one French franc to 75 Comoros francs to one French franc at the same time.
} 
Results. The CFA devaluation has had excellent intermediate-term effects on growth. For the 12 CFA countries in Devarajan's sample, real GDP growth from 1990 to 1993 averaged almost negative 0.3 percent annually weighted by GDP, according to World Bank data (World Bank, 1999). However, from 1994 to 1997, growth in these same countries averaged 5.1 percent annually, according to the same data source. ${ }^{23}$ Cameroon, the largest country in the CFA zone, grew at an annual rate of -3.4 percent in the first period, but 4.5 percent in the second period (World Bank, 1999). Devarajan found that a year after the devaluation, the average undervaluation was two percent for the group, but with significant variance.

\section{Lessons from Africa}

The countries of Sub-Saharan Africa have made significant strides in correctly valuing their exchange rates. In 1980, 45 African countries had pegged exchange rates, four had managed floats, and none had independent floats. By 1996, 25 had pegged exchange rates, six had managed floats, and fully 19 had indeperdent floats, according to Sekkat and Varoudakis. In both years, 14 were pegged to the French franc. This move towards a flexible exchange rate allowed most non-CFA zone countries to experience a real depreciation, starting in 1984-5. The CFA zone countries had their own depreciation in 1994.

By the late 1990s, much of Africa had returned to growth. Hernández-Catá (1999) reported that real GDP grew 4.25 percent annually from 1995 to 1998 , up from less than 1.5 percent from 1990 to 1994, with per capita output up one percent in the later period, against a decline of 2.25 percent in the earlier period. Inflation peaked at 47 percent in 1994, and dropped to 10 percent 1998 . He credited the improved performance to better policy rather than external developments, which were adverse in 1998.

A great deal of policy reform remains for Africa. Though policy makers have taken large steps, there has been backsliding and failure to implement some important measures. Aggregate growth has returned, but per capita growth is only slightly positive and investment and savings both remain lower than in other developing regions. However, the continent has seen significant successes, and a realistically valued exchange rate has proved essential to these.

\section{Diverse versus Uniform Tariffs and Incentives}

In defense of the exchange rate, countries often apply trade protection that is very high or prohibitive on selected products or countries. The experience in Kazakhstan in early 1999 is a case in point. We question the efficacy of these policies. Even with a limited objective of reducing the demand for foreign exchange, depending on how porous the borders are, we will observe an increase in imports through informal channels. And with diverse protection, while some sectors will be protected, the burden of the costs of

${ }^{23}$ The unweighted averages are 0.1 percent for 1990 to 1993 and 4.7 percent for 1994 to 1995. 
adjustment to the overvalued exchange rate will be borne by the unprotected sectors, those sectors that are more susceptible to informal or illegal imports, and the export sectors.

Although protection is unlikely the appropriate response to a balance of payments crisis, if any protection is offered for this purpose, it should be uniform, not a diverse protection structure. ${ }^{24}$ A uniform tariff is sometimes applied for balance of payments reasons; this achieves the same impact on reducing imports as exchange rate depreciation, but it fails to achieve the beneficial effects on the export side. The optimal tariff structure, given that it is a surrogate for a devaluation (without export incentives), must uniformly induce resources to flow into import competing industries in general rather than any particular import competing industry.

At the practical level, the arguments for a diverse tariff structure rest on the ability of governments to: (i) "pick the winners," that is to identify the candidates that are most likely to meet the conditions justifying intervention, and choose and maintain the appropriate level for the policy variable (tariff, subsidy). In general, the market is a more reliable indicator of the industries that have comparative advantage than any economic model. Over time this is particularly true, as comparative advantage changes with technological development; (ii) be immune to the pressures from vested groups that inevitably arise once the willingness to grant special status is established; and (iii) prevent any protection granted from becoming permanent.

The empirical evidence in both developed and developing countries during the past three decades casts doubt on most governments' ability to meet these conditions. Endorsement of a more general approach - with little differentiation in the level of assistance - thus emanates from a wider skepticism about the practical merits of targeting of any kind. ${ }^{25}$

Moreover, the economy must provide its most talented members with the incentive to engage in entrepreneurial activities such as starting or expanding firms, developing new products and lowering costs. If the economy provides tariffs that differ greatly by sector, or extensive subsidies or tax exemptions to industries or firms, or presents a difficult regulatory framework within which to do business, talented people will find it more profitable to engage in the socially, wasteful activity of lobbying the government for tariffs, subsidies, protection, tax or regulatory relief (Murphy, Shleifer and Vishny, 1991). This socially wasteful lobbying is especially harmful because it attracts one of the scarcest resources in developing countries: entrepreneurial talent that would otherwise be helping the economy grow. Thus, World Bank experience indicates (see Leiberman, 1990; Atiyas et al. 1992) that the best industrial policy is for the government to provide a stable macroeconomic and regulatory environment conducive to business development with neutral incentives to all firms and industries.

\footnotetext{
${ }^{24}$ See Tarr (1998) for an elaboration of the arguments for and against a uniform tariff.

${ }^{25}$ See Westphal $(1990)$ and Krugman $(1989,1992)$ for details.
} 


\section{References}

Atiyas, Izak, Mark Dutz, and Claudio Frischtak, with Bita Hadjimichael (1992), Fundamental Issues and Policy Approaches in Industrial Restructuring, Industry Series Paper No. 56, The World Bank, April.

Azam, Jean-Paul and Shantayanan Devarajan (1997), "The CFA. Franc Zone in Africa: A Syposium." Journal of African Economies, Vol. 6, No. 1, March, pp. 1-2.

Bouton, Lawrence, Christine Jones, and Miguel Kiguel (1994), "Macroeconomic Reform and Growth in Africa, Adjustment in Africa Revisited." Policy Research Working Paper 1394, The World Bank, December.

Cardoso, Eliana and Albert Fishlow (1989), "Latin American Economic Development: 1950-1980," (NBER Working Paper No. 3161). Cambridge, Mass.: National Bureau of Economic Research, November.

Clément, Jean A.P. (1994), "Striving for Stability: CFA Franc Fiealignment," Finance and Development, Vol. 31, No. 2, June, pp. 10-13.

Corbo, Vittorio, Jaime de Melo and James Tybout (1986), "What Went Wrong with the Recent Reforms in the Southern Cone," Economic Development and Cultural Change, Vol. 34, No. 3, April, pp. 607-640.

Corbo, Vittorio and Jaime de Melo (1987), "Lessons From the Southern Cone Policy Reforms," The World Bank Research Observer, Vol. 2, No. 2, July, pp. 111-142.

Corbo, Vittorio and Stanley Fischer (1994), "Lessons from the Chilean Stabilization and Recovery." Chapter 1 in Barry P. Bosworth, Rudiger Dornbusch, and Raúl Labán, The Chilean Economy: Policy Lessons and Challenges. Washington, D.C.: The Brookings Institution.

Dornbusch, Rudiger and Sebastian Edwards (1994), "Exchange Rate Policy and Trade Strategy. " Chapter 2 in Barry P. Bosworth, Rudiger Dornbusch, and Raúl Labán, The Chilean Economy. Policy Lessons and Challenges. Washington, D.C.: The Brookings Institution.

Clément, Jean A.P., with Johannes Mueller, Stéphane Cossé, and Jean Le Dem (1996), Aftermath of the CFA France Devaluation (Occasional Paper 138). Washington, D.C.: International Monetary Fund, May.

Cottani, Joaquin A., Domingo F. Cavallo and M. Shahbaz Khan (1990), "Real Exchange Rate Behavior and Economic Performance in LDCs," Economic Development and Cultural Change, Vol. 39, No. 1, October, pp. 61-76. 
Demery, David and Lionel Demery (1992), Adjustment and Equity in Malaysia. Report in the Series, Adjustment and Equity in Developing Countries, Christian

Morrisson, general editor. Paris: Organization for Economic Cooperation and Development.

Devarajan, Shantayanan (1997), "Real Exchange Rate Misalignment in the CFA Zone." Journal of African Economies, Vol. 6, No. 1, March, pp. 35-53.

Devarajan, Shantayanan and Lawrence E. Hinkle (1994), "The CFA Franc Parity Change: an opportunity to restore growth and reduce poverty." Africa Spectrum, Vol. 29, No. 2, pp. 131-151.

Dollar, David (1992), "Outward Oriented Countries Do Grow More Rapidly," Economic Development and Cultural Change.

Edwards, Sebastian (1988), Exchange Rate Misalignment in Developing Countries (Occasional Paper Number 2/New Series). Baltimore and London: The Johns Hopkins University Press (for The World Bank).

Edwards, Sebastian (1989), "Exchange Rate Misalignment in Developing Countries," The World Bank Research Observer, Vol. 4, No. 1, January, pp. 3-21.

Edwards, Sebastian (1993), "Openness, Trade Liberalization and Growth in Developing Countries," Journal of Economic Literature, Vol. 31.

Elbadawi, Ibrahim and Nader Majd (1996), “Adjustment and Economic Performance Under a Fixed Exchange Rate: A Comparative Analysis of the CFA Zone." World Development, Vol. 24, No. 5, May, pp. 939-951.

Faini, Riccardo and Jaime de Melo (1990), "Adjustment, investment and the real exchange rate in developing countries," Economic Policy, October, pp. 492-519.

Finger, J. Michael (1991), "Trade Policy in the United States," in D. Salvatore (ed.), A Handbook of Trade Policies, Westport Connecticut, Greenwood Publishing Group.

Finger, J. Michael (1996), "Legalized Backsliding: Safeguards Provisions in GATT," in Will Martin and L. Alan Winters, eds., The Uruguay Round and the Developing Countries, Cambridge: Cambridge University Press.

Foroutan, Faezeh (1997), "Preconditions and Sustainability of Reforms." Chapter 5 in John Nash and Faezeh Foroutan, eds., Trade Policy and Exchange Rate Reform in Sub-Saharan Africa (Development Issues Number Six). Canberra: National Centre for Development Studies. 
Ghei, Nita and Lant Pritchett (1999), "The Three Pessimisms: Real Exchange Rates and Trade Flows in Developing Countries," in Hinkle and Montiel (eds.) Exchange Rate Misalignment: Concepts and Measurement for Developing Countries, A World Bank Research Publication, New York: Oxford University Press.

Ghei, Nita and Stephen B. Kamin (1999), "The Use of the Parallel Market Rate as a Guide to Setting the Official Exchange Rate," in Hinkle and Montiel (eds.) Exchange Rate Misalignment: Concepts and Measurement for Developing Countries, A World Bank Research Publication, New York: Oxford University Press.

Ghei, Nita and Lawrence E. Hinkle (1999), "A Note on Nominal Devaluations, Inflation and the Real Exchange Rate," in Hinkle and Montiel (eds.) Exchange Rate Misalignment: Concepts and Measurement for Developing Countries, A World Bank Research Publication, New York: Oxford University Press.

Ghura, Dhaneshwar and Thomas J. Grennes (1993), "The Real Exchange Rate and Macroeconomic Performance in Sub-Saharan Africa," Journal of Development Economics, Vol. 42, No. 1, October, pp. 155-174.

Global Currency Report (1999), Vol. 44, No. 1, January-February-March, Brooklyn, N.Y.: Currency Data \& Intelligence, Inc.

Hernández-Catá, Ernesio (1999), "Sub-Saharan Africa: Economic Policy and Outlook for Growth," Finance and Development, Vol. 36, No. 1, March, pp. 10-12.

Hinkle, Lawrence E. and Peter J. Montiel, eds. (1999), Exchange Rate Misalignment: Concepts and Measurement for Developing Countries, A World Bank Research Publication, New York: Oxford University Press.

International Monetary Fund (1999), Annual Report on Exchange Arrangements and Exchange Restrictions, 1999, Washington, D.C.: International Monetary Fund.

Jones, Christine and Miguel Kiguel (1994), "Africa's Quest for Prosperity: Has Adjustment Helped?" Finance and Development, Vol. 31, No. 2, June 1994, pp. $2-5$.

Keynes, John Maynard (1925), "The Economic Consequences of Mr. Churchill," in Essays in Persuasion (The Norton Library, 1963), New York: W.W. Norton \& Company, Inc., pp. 244-270.

Klau, Marc (1998), "Exchange Rate Regimes and Inflation and Output in Sub-Saharan Countries." Basle: Bank for International Settlements Working Papers No. 53 (Monetary and Economic Department; March). 
Krueger, Anne O. (1995), "Partial Adjustment and Growth in Turkey," Chapter 11 in Rudiger Dornbusch and Sebastian Edwards, eds., Reform, Recovery and Growth: Latin America and the Middle East (A National Bureau of Economic Research Project Report). Chicago: The University of Chicago Press.

Krugman, P. A. (1989), "Is Free Trade Passe," Journal of Economic Perspetives, Vol. 1, pp. 131-144.

—_ (1992), "Does the New Trade Theory Require a New Trade Policy," World Economy, Vol. 15, pp. 423-442.

Labán, Raúl and Felipe Larraín (1995), "Continuity, Change, and the Political Economy of Transition in Chile," Chapter 4 in Rudiger Dornbusch and Sebastian Edwards, eds., Reform, Recovery and Growth: Latin America and the Middle East (A National Bureau of Economic Research Project Report). Chicago: The University of Chicago Press.

Leiberman, Ira (1990), Industrial Restructuring: Policy and Practice, Policy and Research Series No. 9, Washington D.C.: The World Bank.

Lewis, Jeffrey D. and Malcolm F. McPherson (1994), "Macroeconomic Management: To Finance or Adjust?"' Chapter 4 in David L. Lindauer and Michael Roemer, eds., Asia and Africa: Legacies and Opportunities in Development. San Francisco: ICS Press (A Copublication of the International Center for Economic Growth and the Harvard Institute for International Development).

Murphy, Kevin, Andrei Shleifer and Robert Vishny (1991), "The Allocation of Talent: Implications for Growth," Quarterly Journal of Economics, Vol. 106, No. 2, May, pp. 503-530.

Nam, Chong-Hyun (1995), "The Role of Trade and Exchange Rate Policy in Korea's Growth." Chapter 6 in Takatoshi Ito and Anne O. Krueger, eds. Growth Theories in Light of the East Asian Experience, (National Bureau of Economic Research East Asia Seminar on Economics, Vol. 4). Chicago: The University of Chicago Press.

Nash, John (1997), "Two Steps Forward, One Back." Chapter 2 in John Nash and Faezeh Foroutan, eds., Trade Policy and Exchange Rate Reform in Sub-Saharan Africa (Development Issues Number Six). Canberra: National Centre for Development Studies.

Nashashibi, Karim and Stefania Bazzoni (1994), "Exchange Rate Strategies and Fiscal Performance in Sub-Saharan Africa," IMF Staff Papers, Vol. 41, No. 1, March, pp. 76-122. 
Nowak, Michael, Rifaat Basanti, Balazs Horvath, Kalpana Kociahar, and Roohi Prem (1996), "Ghana, 1983-91." Chapter III (pp. 22-47) in Michael T. Hadjimichael, Michael Nowak, Robert Sharer, Amor Tahari, and a Staff Team from the African Department. Adjustment for Growth: The African Experience. Washington, D.C.: International Monetary Fund (October).

Pritchett, Lant (1997), "Economic Growth: Hills, Plains, Mountains, Plateaus and Cliffs," Mimeo, The World Bank (October 9).

Roemer, Michael (1994), "Asia and Africa: Towards a Development Policy Frontier," Cambridge, Mass.: Development Discussion Paper No. 485, Harvard Institute for International Development (April).

Sachs, Jeffrey and Felipe Larrain (1999), "Why Dollarization Is More Straitjacket Than Salvation," Foreign Policy, Fall, pp. 80-92.

Sachs, J. D. and A. Warner (1995), "Economic Reform and the Process of Global Integration," Brookings Papers on Economic Activity, W. C. Brainard and G. L. Perry, eds., Washington, D.C., pp. 1-117.

Sekkat, Khalid and Aristomène Varoudakis (1998), "Exchange-Rate Management and Manufactured Exports in Sub-Saharan Africa," Paris: OECD Development Center Technical Papers No. 134 (March).

Summers, Robert and Alan Heston (1991), "The Penn World Table (Mark 5): An Expanded Set of International Comparisons, 1950-1988," Quarterly Journal of Economics, Vol. 106, No. 2, May, pp. 327-368.

Tarr, David G. (1999), "The Design of Optimal Tariff Policy for Russia," in Harry Broadman, ed., Russian Trade Policy: Reform for WTO Accession, Washington D.C.: The World Bank.

Tarr, David G. (1994), "The Welfare Costs of Price Controls for Cars and Color Televisions in Poland: Contrasting Estimates of Rent-Seeking from Recent Experience," The World Bank Economic Review, Vol. 8, No. 3, September, pp. 415-443.

Tarr, David G. (1990), "Second-Best Foreign Exchange Policy in the Presence of Domestic Price.Controls and Export Subsidies," The World Bank Economic Review, Vol. 4, No. 2, May, pp. 175-193.

Tarr, David G. (1990a), "Quantifying Second Best Effects in Grossly Distorted Markets: The Case of the Butter Market in Poland," Journal of Comparative Economics, Vol. 14, March, pp. 105-119.

Torres, Craig (1999), "Chile Suspends Trading Band on its Peso: New Free-Floating System is Intended to Stimulate Export-Led Expansion," Wall Street Journal, September 7, p. A21. 
U.S. Bureau of the Census (1975), Historical Statistics of the United States: Colonial Times to 1970, Part I, Bicentennial Edition. Washington, D.C.: The Bureau.

Westphal, L.E. (1990), "Industrial Policy in an Export-propelled Economy: Lessons from South Korea's Experience," Journal of Economic Perspectives, Vol. 4, pp. 41-60.

World Bank (1995), Ghana: Growth, Private Sector, and Poverty Reduction. A Country Economic Memorandum. Washington, D.C.: World Bank, Country Operations Division, West Central Africa Department (May 15).

World Bank (1999), World Development Indicators (Electronic Database). Washington, D.C.: The World Bank. 



\section{Policy Research Working Paper Series}

\begin{tabular}{|c|c|c|c|c|}
\hline & Title & Author & Date & $\begin{array}{l}\text { Contact } \\
\text { for paper }\end{array}$ \\
\hline WPS2265 & $\begin{array}{l}\text { The Political Economy of Distress } \\
\text { In East Asian Financial Institutions }\end{array}$ & $\begin{array}{l}\text { Paola Bongini } \\
\text { Stijn Claessens } \\
\text { Giovanni Ferri }\end{array}$ & January 2000 & $\begin{array}{l}\text { R. Vo } \\
33722\end{array}$ \\
\hline WPS2266 & $\begin{array}{l}\text { The Impact of Adult Deaths on } \\
\text { Children's Health in Northwestern } \\
\text { Tanzania }\end{array}$ & $\begin{array}{l}\text { Martha Ainsworth } \\
\text { Innocent Semali }\end{array}$ & January 2000 & $\begin{array}{l}\text { S. Fallon } \\
38009\end{array}$ \\
\hline WPS2267 & $\begin{array}{l}\text { Do High Interest Rates Defend } \\
\text { Currencies during Speculative Attacks }\end{array}$ & $\begin{array}{l}\text { Aart Kraay } \\
\text { s? }\end{array}$ & January 2000 & $\begin{array}{l}\text { R. Bonfield } \\
31248\end{array}$ \\
\hline WPS2268 & $\begin{array}{l}\text { The Structure of Social Disparities } \\
\text { in Education: Gender and Wealth }\end{array}$ & Deon Filmer & January 2000 & $\begin{array}{l}\text { S. Fallon } \\
38009\end{array}$ \\
\hline WPS2269 & $\begin{array}{l}\text { Context Is Everything: Measuring } \\
\text { Institutional Change in Transition } \\
\text { Economies }\end{array}$ & Nauro F. Campos & January 2000 & $\begin{array}{l}\text { J. Victor } \\
36549\end{array}$ \\
\hline WPS2270 & $\begin{array}{l}\text { The Optimal Income Tax When } \\
\text { Poverty is a Public "Bad" }\end{array}$ & Waly Wane & January 2000 & $\begin{array}{l}\text { H. Sladovich } \\
37698\end{array}$ \\
\hline WPS2271 & Corporate Risk around the World & $\begin{array}{l}\text { Stijn Claessens } \\
\text { Simeon Djankov } \\
\text { Tatiana Nenova }\end{array}$ & January 2000 & $\begin{array}{l}\text { R. Vo } \\
33722\end{array}$ \\
\hline WPS2272 & $\begin{array}{l}\text { Ownership versus Environment: } \\
\text { Disentangling the Sources of Public } \\
\text { Sector Inefficiency }\end{array}$ & $\begin{array}{l}\text { Ann P. Bartel } \\
\text { Ann E. Harrison }\end{array}$ & January 2000 & $\begin{array}{l}\text { S. Fallon } \\
38009\end{array}$ \\
\hline WPS2273 & $\begin{array}{l}\text { The Value of Preventing Malaria } \\
\text { In Tembien, Ethiopia }\end{array}$ & $\begin{array}{l}\text { Maureen L. Cropper } \\
\text { Mitiku Haile } \\
\text { Julian A. Lampietti } \\
\text { Christine Poulos } \\
\text { Dale Whittington }\end{array}$ & January 2000 & $\begin{array}{l}\text { T. Tourougui } \\
87431\end{array}$ \\
\hline WPS2274 & $\begin{array}{l}\text { How Access to Urban Potable Water } \\
\text { and Sewerage Connections Affects } \\
\text { Child Mortality }\end{array}$ & Anqing Shi & January 2000 & $\begin{array}{l}\text { P. Sintim-Aboagye } \\
37644\end{array}$ \\
\hline WPS2275 & $\begin{array}{l}\text { Who Gained from Vietnam's Boom } \\
\text { In the 1990s? An Analysis of Poverty } \\
\text { An Analysis of Poverty and } \\
\text { Inequality Trends }\end{array}$ & $\begin{array}{l}\text { Paul Glewwe } \\
\text { Michele Gragnolati } \\
\text { Hassan Zaman }\end{array}$ & January 2000 & $\begin{array}{l}\text { P. Sader } \\
33902\end{array}$ \\
\hline WPS2276 & $\begin{array}{l}\text { Evaluating the Case for Export } \\
\text { Subsidies }\end{array}$ & Arvind Panagariya & January 2000 & $\begin{array}{l}\text { L. Tabada } \\
36896\end{array}$ \\
\hline
\end{tabular}




\section{Policy Research Working Paper Series}

Title

$\begin{aligned} & \text { WPS2277 Determinants of Bulgarian Brady } \\ & \text { Bond Prices: An Empirical } \\ & \text { Assessment }\end{aligned}$
$\begin{aligned} & \text { WPS2278 Liquidity Constraints and Investment } \\ & \text { in Transition Economies: The Case } \\ & \text { of Bulgaria }\end{aligned}$
WPS2279 Broad Roads in a Thin Country:
Infrastructure Concessions in Chile

WPS2283 New Tools and New Tests in Comparative Political Economy: The Database of Political Institutions

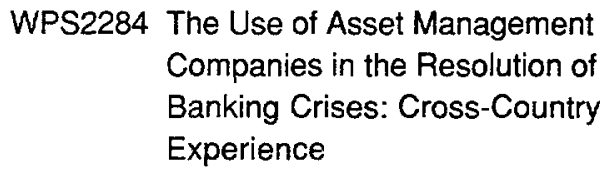
Companies in the Resolution of Banking Crises: Cross-Country Experience

WPS2285 Industrial Environmental Performance Susmita Dasgupta in China: The Impacts of Inspections Benoit Laplante

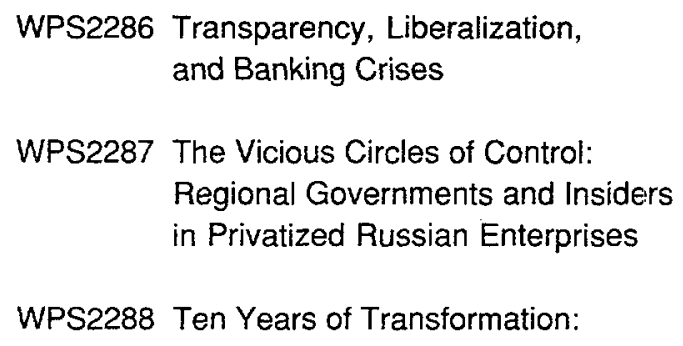
and Banking Crises

WPS2287 The Vicious Circles of Control: Regional Governments and Insiders in Privatized Russian Enterprises

WPS2288 Ten Years of Transformation: Macroeconomic Lessons Nlandu Mamingi Hua Wang

Author

Nina Budina

Tzvetan Mantchev

Nina Budina

Harry Garretsen

Andrés Gómez-Lobo

Sergio Hinojosa

Hua Wang

Dale Whittington

César Calderón

Norman Loayza

Hana Polackova Brixi Sergei Shatalov

Leila Zlaoui

Thorsten Beck

George Clarke

Alberto Groff

Philip Keefer

Patrick Walsh

Daniela Klingebiel

Gil Mehrez

Daniel Kaufmann

Raj M. Desai

Itzhak Goldberg

Charles Wyplosz
Date

January 2000

January 2000

January 2000

January 2000

January 2000

January 2000

February 2000

Februaly 2000

February 2000

February 2000

February 2000

Y. D'Souza 31449

D. Bouvet 35818

S. Cox 36633

February 2000

M. Jandu
Contact for paper

N. Budina 82045

N. Budina 82045

G. Chenet-Smith 36370

R. Yazigi

37176

H. Vargas 38546

L. Zlaoui

33100

P. Sintim-Aboagye 38526

R. Vo 33722

33103 